Vol. 5 No.1 (2021) pp. 59 - 69

Available online at: http://jurnal.umpwr.ac.id/index.php/abdimas/index

p-ISSN: 2580-3492 e-ISSN: 2581-0162

\title{
Penerapan Program Literasi Melalui Taman Bacaan Masyarakat Oemah Cendekia di Kelurahan Kedungsari Kabupaten Purworejo
}

\author{
Ade Sabda Gumelar $\bowtie$, Eny Ngesti Utami, Arif Setyadi \\ Universitas Muhammadiyah Purworejo \\ Jl. K.H. A. Dahlan 3 Purworejo, Jawa Tengah, Indonesia \\ | adesabdagumelar@gmail.com $\bigotimes$ | DOI: https://doi.org/10.37729/abdimas.v5i1.794 |
}

\begin{abstract}
Abstrak
Program literasi melalui taman bacaan masyarakat oemah cendekia terletak di Desa Kedungsari Kabupaten Purworejo. Mayoritas masyarakat di Desa Kedungsari belum mendapatkan pendidikan yang sesuai harapan. Sebagian besar penduduknya adalah petani yang hanya bertamatkan jenjang pendidikan yang minim sehingga kesulitan dalam mendampingi anak anaknya dalam hal pendidikan. Sehingga dalam pelaksanaan program literasi melibatkan pemuda karangtaruna sebagai mitra program penerapan literasi melalui taman bacaan masyarakat. Mitra program mayoritas siswa SMP dan SMA yang masih haus akan ilmu namun perlu banyaknya pendampingan. Oleh sebab itu tujuan dari program literasi melalui taman bacaan masyarakat oemah cendekia agar saling mencerdaskan kehidupan bangsa dengan bertransformasi menjadi masyarakat berkemajuan dengan pendampingan IPTEK namun tetap mengedepankan moral. Metode pelaksanaan yang digunakan adalah Persiapan - Penyusunan LiterasiPelaksanaan Program - Evaluasi dan dalam setiap tahap selalu ada pendampingan dari tim terhadap mitra. Persiapan terdiri dari kesiapan tim, kondisi mitra, materi dan kesepakatan jadwal. Penyusunan literasi terdiri dari buku bacaan dan media pembelajaran. Pelaksanaan program terdiri dari pendirian perpustakaan, kreatifitas, keilmuan dan kepedulian sosial. Persentase penerima manfaat program di taman bacaan Rw 01 50,70 \%, taman bacaan Rw 02 70,00\%, taman bacaan Rw 03 dengan persentase penerima manfaat tertinggi yaitu 78,79\%, taman bacaan Rw 04 58,85\%, taman bacaan Rw 05 dengan persentase penerima manfaat terendah yaitu 42,86\%. Dengan total persentase keseluran adalah 57,30\% yang berarti penerapan program literasi melalui taman bacaan masyarakat oemah cendekia di Kabupaten Purworejo sudah terlayani.
\end{abstract}

Kata kunci: Program literasi, Taman bacaan, Oemah cendekia

\section{Pendahuluan}

Kemampuan literasi di masyarakat perlu terus ditingkatkan sebagai upaya secara sadar agar masyarkat memiliki kemampuan dan ketrampilan dalam hal pengetahuan dan teknologi. Melalui literasi wawasan masyarakat semakin luas dan memiliki pola pikir yang logis dan kritis (Suryaman, M.,2015). Dalam pembelajaran konstruk literasi dirancang sedemikian rupa agar dapat meningkatkan pemahaman peserta didik dalam aspek-aspek literasi itu sendiri, misalnya literasi membaca, literasi sains, literasi matematis, dan sebagainya (Musfiroh, T., \& Listyorini, B., 2016). Sementara kemampuan literasi merupakan keterampilan dasar yang memberi dampak signifikan dan mendukung keterampilan lain yang lebih kompleks. Untuk meningkatkan kemampuan literasi matematika siswa, guru sebagai aktor dalam pembelajaran memegang peranan 
penting. Proses belajar dan mengajar yang dirancang guru akan mempengaruhi persepsi, minat, pengetahuan dan kemampuan siswa. Upaya yang dapat dilakukan guru dalam meningkatkan kemampuan literasi matematika siswa adalah dimulai dengan membantu siswa dalam membangun persepsi positif terhadap membaca, matematika, maupun sains (Susanti, E., \& Syam, S. S.,2017).

Desa Kedungsari merupakan desa yang hidup berdampingan dengan pondok pesantren tradisional yang mengedepankan ilmu agama dan mayoritas santri hanya bersekolah sampai tingkatan sekolah dasar atau sekolah menengah pertama. Berbeda dengan masyarakat pribumi yang sebagian besar menginginkan sekolah hingga SMA atau SMK dan kemudian berharap langsung bekerja dan tidak banyak yang memilih untuk melanjutkan ke perguruan tinggi karena permasalahan biaya.

Banyak pemuda yang setelah menyelesaikan pendidikan kemudian bekerja di perantauan namun hanya satu atau dua tahun kemudian kembali lagi ke desa untuk menjadi buruh tani karena tidak ada harapan lagi untuk bekerja yang didasari pada kurangnya keahlian dan umur. Hal itu juga disebabkan karena adanya sistem kontrak kerja yang diberlakukan oleh perusahaan kepada karyawan. Permasalahan yang muncul akhirnya berpengaruh dengan adanya ketidakselarasan kehidupan yang dibangun oleh pondok pesantren dengan kehidupan masyarakat pribumi yang menginginkan generasi mudanya memiliki wawasan dan cakrawala serta keahlian khusus, sehingga kedepannya mampu membangun desa demi harapan yang cerah. Situasi dan kondisi tersebut yang menyebabkan terhalangnya pengembangan wawasan karena tidak adanya tempat untuk literasi dan mengembangkan potensi untuk masyarakat. Upaya untuk menggiatkan literasi sejatinya telah digalakkan oleh berbagai pihak, Soleh, K., \& Nurhidayati, N. (2017) mengupayakan kegiatan literasi untuk tingkat SD maupun MI pada tingkat kecerdasan majemuk. Hal senada telah dilakukan oleh Suryaman, M. (2015) terkait analisis hasil belajar peserta didik dalam literasi membaca melalui studi internasional (PIRLS). Literasi sanis pada peserta didik juga telah dikaji oleh Yuliati, Y. (2017), dan Asyhari, A. (2015).

Desa Kedungsari Kecamatan Purworejo Kabupaten Purworejo memiliki kelompok pemuda karangtaruna diberbagai dusun. Kelompok karangtaruna di Desa Kedungsari mayoritas berpendidikan Sekolah Menengah Pertama (SMP) dan Sekolah Menengah Atas (SMA) yang di mana usia tersebut masih haus akan ilmu. Namun disisi lain dari setiap RW (Rukun Warga) di Desa Kedungsari hanya sebagian karangtaruna yang masih aktif, kondisi tersebut dikarenakan perihal banyaknya pemuda setelah menamatkan pendidikannya berurbanisasi demi memperbaiki nasib yang lebih layak yang walau kenyataannya hanya bertahan beberapa tahun setelah itu kembali pulang ke kampung halaman tanpa membawa harapan. Melihat peluang dan potensi serta beberapa kelemahan yang perlu diperbaiki dari kelompok pemuda karangtaruna di Desa Kedungsari, atas dasar hal tersebut kelompok pemuda karangtaruna dijadikan sebagai mitra program literasi melalui taman bacaan masyarakat di Desa Kedungsari Purworejo.

Melihat kebutuhan program tamaan bacaan masyarakat di desa Kedungsari, dalam pengembangan IPTEK (Ilmu Pengetahuan Teknologi). Program literasi melalui taman bacaan masyarakat melibatkan mitra luar (eksternal) Desa Kedungsari, yaitu bermitra dengan Program Studi Teknologi dan Informasi (PSTI) Universitas Muhammadiyah Purworejo dengan tujuan dapat mengembangkan keilmuan melalui perangkat digital atau platform aplikasi. 
Program literasi melalui taman bacaan masyarakat Oemah Cendekia di Desa Kedungsari Kabupaten Purworejo bertujuan untuk mencerdaskan kehidupan bangsa melalui pendidikan non formal dengan menanamkan cinta akan budaya literasi dan mengembangkan literasi tersebut pada peningkatan softskill, hardskill dan lifeskill disetiap taman bacaan masyarakat.

\section{Metode}

Penerapan program literasi melalui taman bacaan masyarakat Oemah Cendekia dilakukan di Desa Kedungsari Kabupaten Purworejo sebagai mitra dalam kegiatan ini. Kegiatan dilaksanakan selama bulan Agustus 2020 hinga bulan Desember 2020. Tahapan yang dilaksanakan meliputi tahap persiapan, tahap kegiatan, dan evaluasi. Adapun tahapan penerapan program literasi melalui taman bacaan masyarakat Oemah Cendekia dapat dilihat pada Gambar 1.

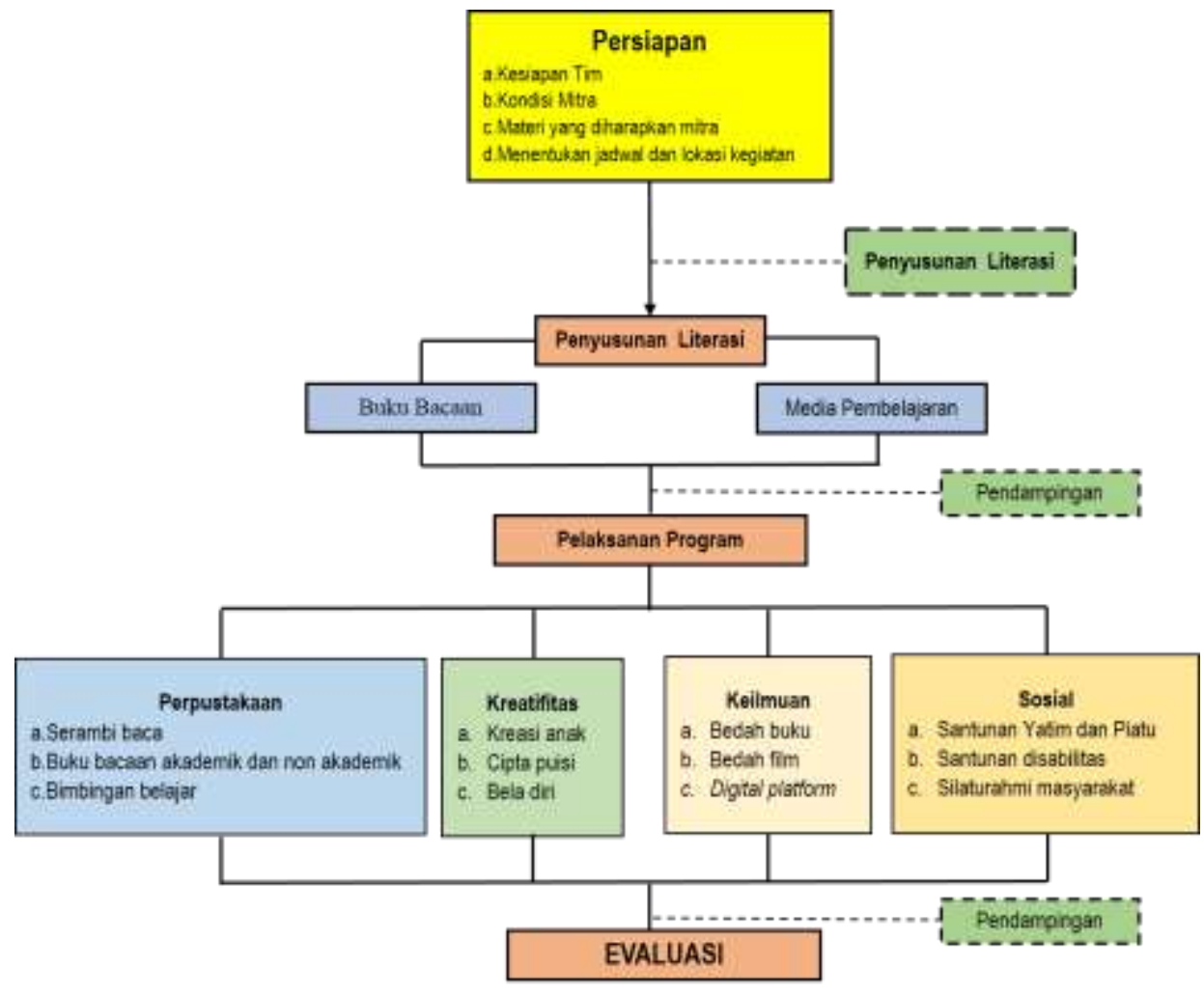

Gambar 1. Alur Tahapan Penerapan Program Literasi Melalui Taman Bacaan Masyarakat

Dalam pelaksanaan kegiatan, tim bekerja secara bersama-sama dan saling berkolaborasi guna melaksanakan setiap tahapan program kerja yang telah direncanakan. Adapun mekanisme pembagian kerja tim dibagi menjadi bagian, yaitu pengurus utama yang meliputi ketua pelaksana, sekretaris, bendahara. Divisi bidang kegiatan meliputi: pembinaan pendidikan, kemitraan dan sarana prasarana, pemberdayaan masyarakat, media informasi dan komunikasi, serta divisi manajemen perpustakaan. Data secara lengkap dapat disajikan pada Tabel 1. 
Tabel 1. Divisi Kerja Tim Oemah Cendekia

\begin{tabular}{ll}
\hline \multicolumn{1}{c}{ Nama } & \multicolumn{1}{c}{ Divisi } \\
\hline Ade Sabda Gumelar & Ketua Pelaksana \\
Eny Ngesti Utami & Sekretaris \\
Rindra Bunga Aulia & Bendahara \\
Annisaa Fauzizah & Pembinaan Pendidikan \\
Elvani Dandi Rizki Pratama & Kemitraan dan Sarana Prasarana \\
Shofan Ghozali & Kemitraan dan Sarana Prasarana \\
Arif Setyadi & Pemberdayaan Masyarakat \\
Andriyan & Pemberdayaan Masyarakat \\
Wahyu Miftakhul Huda & Media Komunikasi dan Teknologi \\
Miko Ariyana & Manajemen Perpustakaan \\
\hline
\end{tabular}

Program literasi melalui taman bacaan masyarakat berdiri di setiap Rw (Rukun Warga) yang ada di Desa Kedungsari dengan koordinator pengelola ditunjukkan pada Tabel 2.

Tabel 2. Koordinator Pengelola Taman Bacaan Setiap Rw

\begin{tabular}{ll}
\hline \multicolumn{1}{c}{ Lokasi } & \multicolumn{1}{c}{ Penanggung Jawab } \\
\hline Rw 01 & Annisaa Fauzizah \\
Rw 02 & Ade Sabda Gumelar dan Andriyan \\
Rw 03 & Arif Setyadi dan Wahyu Miftakhul Huda \\
Rw 04 & Rindra Bunga Aulia, Eny Ngesti Utami \\
& dan Miko Ariyana \\
Rw 05 & Elvani Dandi Rizki Pratama dan Shofan \\
& Ghozali \\
\hline
\end{tabular}

\section{3.. Hasil dan Pembahasan}

3.1 Penerapan Program literasi melalui taman bacaan masyarakat Oemah Cendekia di Kelurahan Kedungsari Kebupaten Purworejo

Taman Bacaan Masyarakat Oemah Cendekia ini merupakan salah satu program pemberdayaan gerakan literasi yang didirikan oleh Tim PHP2D Oemah Cendekia di Kelurahan Kedungsari sebagai salah satu upaya dalam meningkatkan minat baca anak dan remaja yang ada di Kelurahan Kedungsari ini. Hal ini dikarenakan semakin banyak dampak negatif yang ditimbulkan oleh perkembangan teknologi seperti adanya gadget yang berdampak pada minat baca mereka. Sebab dengan adanya perkembangan teknologi ini semua hal sudah dapat diakses di gadget, misalnya saat mereka mempunyai tugas yang harus dikerjakan di rumah mereka cenderung menggunakan gadget untuk membantu mereka menjawab pertanyaanpertanyaan yang diberikan guru atau dosen mereka dibandingkan dengan membaca buku. Tentu saja cara seperti ini lebih praktis daripada membaca buku yang memerlukan waktu lebih lama untuk menjawab pertanyaan yang diajukan.

Selain dipengaruhi oleh perkembangan teknologi, anak-anak di Kelurahan Kedungsari ini kurang mendapat dukungan dalam hal membaca dari orang tua. Hal ini disebabkan oleh tuntutan pekerjaan orang tua mereka sebagai seorang petani yang 
harus menghabiskan waktu di luar rumah dan hanya bertemu anak-anak mereka pada malam hari. Untuk menarik perhatian anak dan remaja terhadap minat baca adalah dengan menerapkan beberapa program kreatif yang akan memicu semangat dan motivasi mereka terhadap minat baca. Tim Oemah Cendekia memiliki empat basis Program literasi yaitu: Serambi baca Cendekia, Sinau Bareng Cendekia, dan Kreasi Cendekia. Program literasi Serambi baca Cendekia menerapkan beberapa kegiatan di antaranya: Serambi baca dan story telling. Adapun penerapan Program literasi tersebut sebagai berikut.

\subsubsection{Serambi Baca Cendekia}

Serambi baca Cendekia merupakan program pojok baca yang dirancang sebagai tempat untuk membaca buku yang sasarannya adalah seluruh lapisan masyarakat, generasi muda, orangtua, maupun anak-anak. Kegiatan di induk serambi baca cendekia dapat ditunjukkan pada Gambar 2.
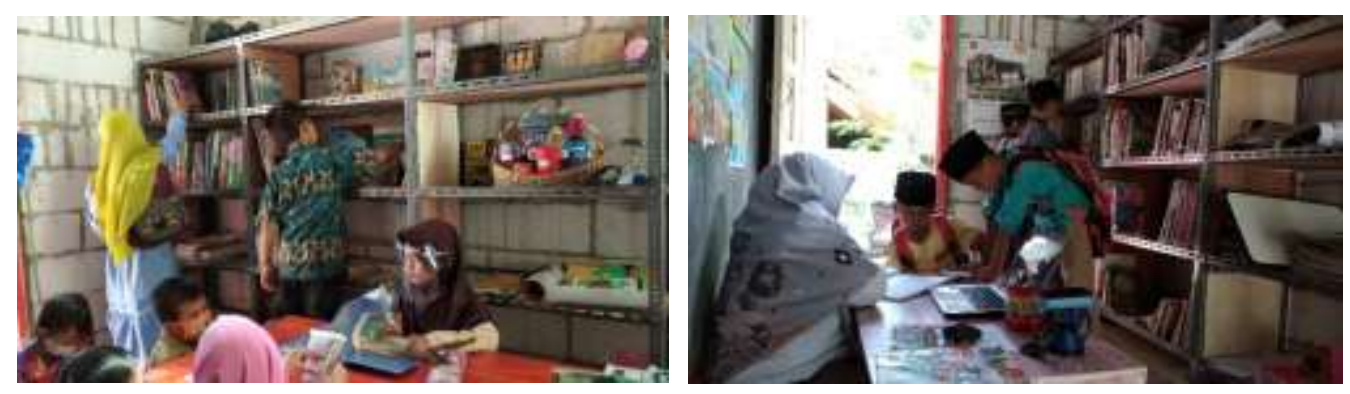

Gambar 2. Induk Serambi Baca Cendekia

Gambar 2 merupakan suasana Induk Serambi baca Cendekia yang digunakan untuk menempatkan buku-buku agar dibaca oleh masyarakat yang berada di sekitarnya. Serambi diisi buku-buku dan alat peraga edukasi. Serambi baca sudah tersebar di 5 tempat. Program-program literasi yang diterapkan pada program Sinau Bareng Cendekia antara lain bimbingan belajar, story telling, dan pemutaran film edukasi.

\subsubsection{Bimbingan Belajar}

Bimbingan belajar merupakan bentuk kegiatan dalam proses belajar yang dilakukan oleh seseorang yang telah memiliki kemampuan lebih dalam banyak hal untuk diberikan kepada orang lain yang mana bertujuan agar orang lain dapat menemukan pengetahuan baru yang belum dimilikinya serta dapat diterapkan dalam kehidupannya. Kegiatan bimbingan belajar disajikan pada Gambar 3. 


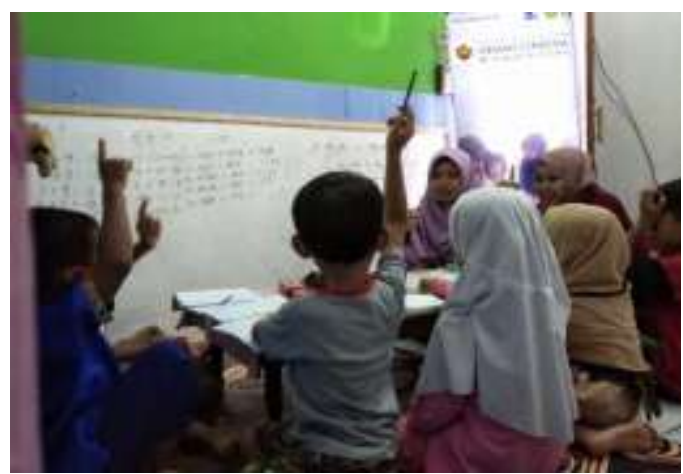

Gambar 3. Bimbingan Belajar

Oemah Cendekia juga memberikan bimbingan belajar pada warga masyarakat terutama siswa-siswa usaia sekolah, yang menjadi salah satu program kegiatan yang dilaksankan oleh anggota Tim Oemah Cendekia. Gambar 2 menunjukkan proses bimbingan belajar mata pelajaran matematika yang diikuti oleh anak-anak dengan sangat antusias.

\subsubsection{Storytelling}

Kegiatan ini merupakan cara yang paling utama dalam menumbuhkan serta meningkatkan minat baca anak. Hal ini disebabkan oleh saat mereka menyaksikan pertunjukan storytelling, motivasi mereka untuk membaca akan muncul dan bertambah. Menurut Ayuni, R. D., Siswati, S., \& Rusmawati, D. (2013) storytelling merupakan sebuah seni bercerita yang dapat digunakan sebagai sarana untuk menanamkan nilai-nilai pada anak yang dilakukan tanpa perlu menggurui sang anak dan cara yang efektif untuk mengembangkan aspek pengetahuan, aspek perasaan, sosial, dan aspek penghayatan anak-anak. Kegiatan storytelling pada Oemah Cendekia dapat ditunjukkan pada Gambar 4.

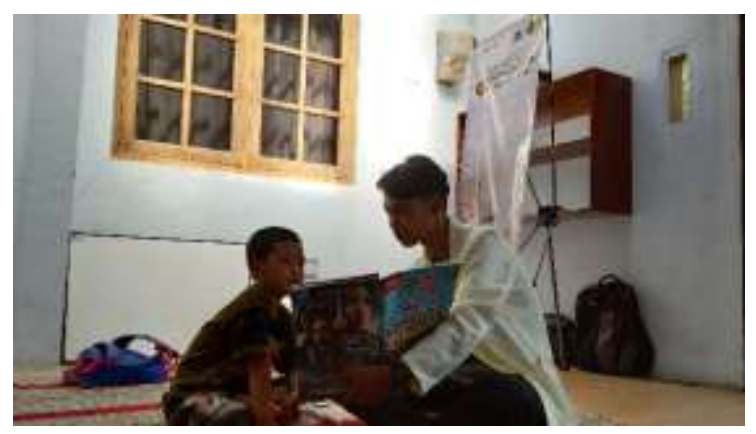

Gambar 4. Storytelling

Berdasarkan Gambar 4 merupakan kegiatan saat salah satu anggota tim oemah cendekia menceritakan tentang salah satu tokoh kartun yang mana anak terlihat sangat antusias mendengar dongeng yang disampaikan oleh anggota tim Oemah Cendekia.

\subsubsection{Pemutaran Film Edukasi}

Pemutaran film edukasi merupakan kegiatan yang mengajak anak-anak untuk menyaksikan film-film dengan tema pendidikan yang sangat diperlukan untuk memenuhi kebutuhan anak-anak dalam mendapatkan hiburan sekaligus pendidikan. 
Tujuan utamanya adalah untuk membuat anak-anak termotivasi kepada film-film edukasi yang baik untuk ditonton dan dapat diambil pelajarannya agar mereka terbiasa untuk menonton film yang menyerupai film tersebut serta menarik minat anak-anak terhadap budaya baca.

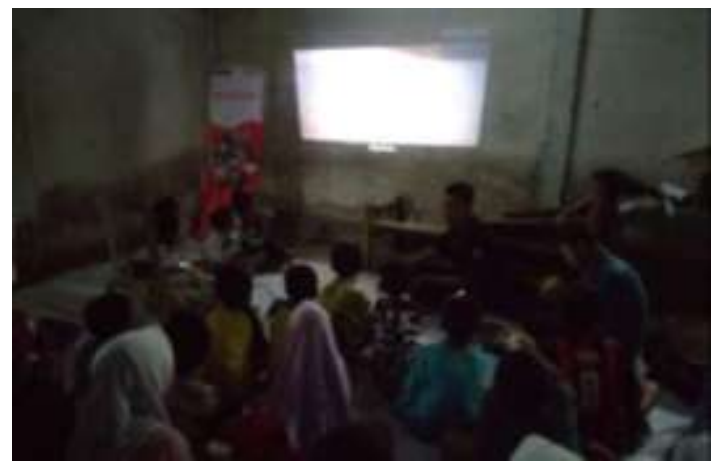

Gambar 5. Kegiatan pemutaran film edukasi

Kegiatan yang dilakukan adalah pemutaran film animasi anak. Pemutaran film ini bertujuan untuk menarik motivasi anak-anak agar mereka lebih meningkatkan lagi minat baca mereka dan juga untuk membangun karakter mereka menjadi lebih baik. Program literasi terakhir adalah Kreasi Cendekia yang menerapkan program kreatif yaitu kreasi anak dan ekonomi kreatif. Adapun penerapan dari program tersebut adalah sebagai berikut.

\subsubsection{Kreasi anak}

Kreasi anak merupakan kegiatan untuk mengajak anak-anak berkreasi, tujuan diadakannya kegiatan ini pertama, dengan berkreasi anak dapat mewujudkan dirinya. Perwujudan diri merupakan salah satu kebutuhan manusia. Kedua, dengan anak selalu berpikir kreatif memungkinkan anak untuk menyelesaikan suatu masalah. Serta anak dapat mengekspresikan pikirannya tanpa ada batasan. Serta dapat melahirkan suatu gagasan baru. Ketiga, dengan menyibukkan diri secara kreatif akan memberikan kepuasan kepada anak. Hal ini karena tingkat kepuasan anak mempengaruhi perkembangan sosial emosional anak. Keempat, dengan kreativitas memungkinkan manusia untuk meningkatkan kualitas dirinya. Beberapa kegiatan yang sudah dilakukan diantaranya kreasi membuat makanan, kreasi menghias sandal dari bahan flannel, kreasi membuat celengan dari kardus bekas, dan kreasi membuat hiasan dinding. Kegiatan kreasi anak ini dapat disajikan pada Gambar 6.

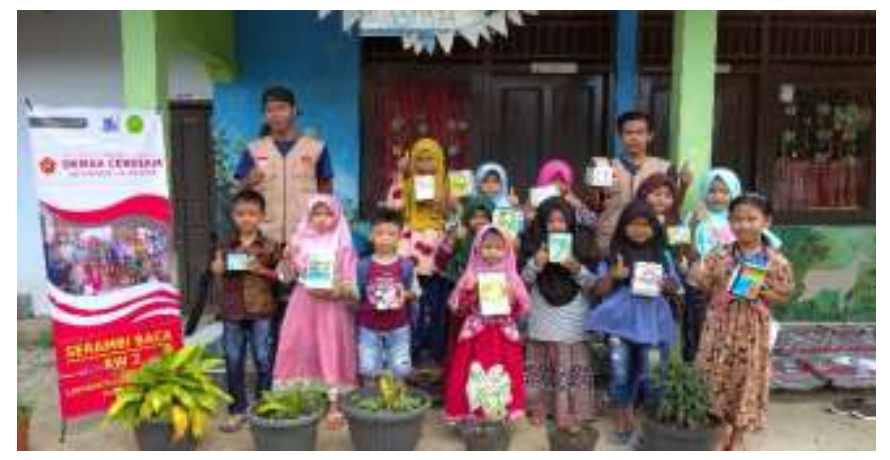

Gambar 6. Kreasi anak membuat celengan dari kardus bekas 
Kegiatan ini bertujuan untuk menarik motivasi anak-anak agar mereka lebih gemar menabung dan mereka terbiasa untuk memanfaatkan barang-barang yang tak terpakai, bisa dimanfaatkan untuk membuat sesuatu yang bermanfaat.

\subsection{Ekonomi Kreatif}

Selain kegiatan edukasi, Oemah Cendekia juga berupaya untuk meningkatkan perekonomian dari kegiatan yang dilakukan, salah satunya dengan membuat kreasikreasi dari bahan-bahan ramah lingkungan. Kegiatan ekonomi kreatif ini salah satunya dengan membuat pernak-pernik atau asesoris berupa bros untuk penghias kerudung dan sebagainya. Pembuatan pernak-pernik ini diinisasi oleh penggiat Oemah Cendekia dan dilaksanakan dengan baik oleh peserta. Proses pembuatan dan produk bross dapat ditunjukkan pada Gambar 7.
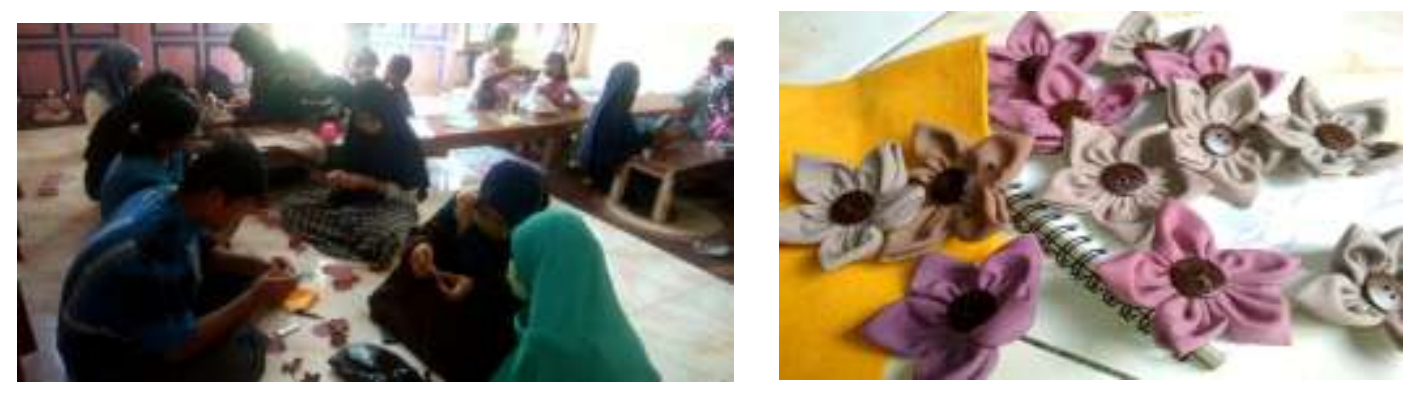

Gambar 6. Proses pembuatan bross

Konsep dari seluruh program kreatif yang diterapkan adalah pendidikan berbasis kebudayaan yang mana memberikan pengajaran tentang kehidupan dan pendidikan bagi anak-anak dengan tujuan untuk membangun karakter sosial dan budaya mereka lebih hidup sehingga menjadikan mereka manusia yang lebih baik dari diri mereka sebelumnya. Seluruh kegiatan program literasi ini berusaha untuk mendidik anak-anak bukan menggurui mereka. Karena mendidik jauh lebih baik dibandingkan hanya menggurui sehingga anak-anak akan jauh lebih menghargai diri mereka.

Saat ini relawan yang telah bersama dengan Oemah cendekia adalah 25 orang yang mana relawan 10 orang merupakan karang taruna kelurahan kedugsari dan 15 orang dari mahasiswa Universitas Muhammadiyah Purworejo yang tergabung dalam Ikatan Mahasiswa Muhammadiyah (IMM). Walaupun kemampuan yang berbeda-beda tetapi para relawan selalu berusaha memberikan pelayanan jasa terbaik dari mereka. Hingga saat ini anak-anak yang menerima manfaat dengan adanya Taman Bacaan Masyarakat oemah cendekia dapat dilihat pada Tabel 3. 
Tabel 3. Data layanan taman bacaan masyarakat Oemah Cendekia

\begin{tabular}{|c|c|c|c|c|}
\hline $\begin{array}{c}\text { Serambi } \\
\text { Baca }\end{array}$ & Lokasi & $\begin{array}{l}\text { Jumlah Anak } \\
\text { Usia TK-SMP }\end{array}$ & Jumlah & $\%$ layanan \\
\hline $\mathrm{I}$ & RW 01 & 71 & 36 & $50,70 \%$ \\
\hline II & RW 02 & 50 & 35 & $70,00 \%$ \\
\hline III & RW 03 & 33 & 26 & $78,79 \%$ \\
\hline IV & RT 02 RW 04 & 21 & 12 & $57,14 \%$ \\
\hline V & RW 05 & 63 & 27 & $42,86 \%$ \\
\hline \multirow[t]{2}{*}{ VI } & RT 01 RW 04 & 22 & 13 & $59,09 \%$ \\
\hline & Total & 260 & 149 & $57,30 \%$ \\
\hline
\end{tabular}

Seperti disajikan pada Tabel 3, daftar anak yang menerima manfaat adanya taman bacaan masyarakat Oemah Cendekia membuktikan bahwa manfaat terebut bisa dirasakan oleh anak usai TK-SMP. Masyarakat kelurahan Kedungsari khususnya anakanak sering memanfaatkan koleksi buku yang ada. Koleksi buku dongeng dan cerita rakyat sering dimanfaatkan oleh anak-anak sebagai bahan belajar seperti belajar mendongeng serta hanya sekedar untuk membaca saja. Lokasi Taman Bacaan Masyarakat Komunitas Ruang Togok Padang Panjang berlokasi di sudut Kota Padang.

Tempat akses menuju taman bacaan tersebut termasuk mudah dan gampang untuk ditemukan. Taman bacaan masyarakat tersebut merupakan sebuah taman bacaan yang berada pada kawasan keramaian yaitu di lingkungan yang mana banyak terdapat anak-anak di dalamnya. Selain itu, taman bacaan masyarakat ini juga bisa membantu meningkatkan ilmu pengetahuan dan pendidikan serta membentuk moral anak-anak yang ada di daerah tersebut. Berdasarkan data yang telah didapat bahwa pengunjung yang datang dalam satu hari dapat mencapai 20 orang dari kalangan anak-anak.

\subsection{Kendala yang Dihadapi dalam Penerapan Program literasi melalui taman bacaan masyarakat di Kelurahan Kedungsari Kabupaten Purworejo}

Berdasarkan hasil observasi tim Oemah Cendekia terdapat beberapa kendala yang dihadapi dalam penerapan literasi di taman bacaan masyarakat Oemah Cendekia sebagai sumber belajar. Kendala yang dihadapi meliputi:

\subsubsection{Koleksi buku}

Koleksi buku yang ada di taman bacaan masyarakat Oemah Cendekia pada umumnya memiliki koleksi buku-buku anak berupa dongeng, cerita-cerita anak, ceritacerita rakyat yang berhubungan dengan anak. Dalam hal ini taman bacaan masyarakat Oemah Cendekia memiliki kendala dalam memenuhi koleksi buku kadang kala untuk mendapatkan koleksi sebuah buku dongeng yang bervariasi sangat susah misalnya buku dongeng yang judulnya berasal dari cerita rakyat. Kebanyakan dalam sebuah banyak buku ada satu cerita rakyat dicetak dalam banyak buku, kendalanya adalah ketika taman bacaan masyarakat Oemah Cendekia ingin memiliki buku dongeng yang bervariasi dari segi judulnya yang berasal dari cerita rakyat sangat susah untuk memenuhinya karena ketersediaan buku tersebut yang sedikit maksudnya edaran bukubuku dongeng tersebut yang sedikit serta akses dalam mendapatkan buku yang bervariasi itu sangatlah kurang. 


\subsubsection{Promosi}

Taman bacaan masyarakat Oemah Cendekia dalam melakukan promosi hanya dengan ruang lingkup yang kecil yaitu dalam lingkungan Taman Bacaan Masyarakat oemah cendekia itu sendiri. Untuk mengajak anak-anak di sekitar kedungsari ke Taman Bacaan Masyarakat oemah cendekia sangat susah karena anak-anak tersebut belum akrab dengan kegiatan-kegiatan seperti, literasi taman bacaan masyarakat.

\subsubsection{Penunjang kegiatan pendidikan}

Salah satunya kendala Taman Bacaan Masyarakat dalam menunjang pendidikan yaitu kurangnya relawan atau tim pengajar, karena relawan atau tim pengajar tersebut tidak selalu berada di Taman Bacaan Masyarakat bisa dibilang tidak selalu hadir. Walaupun ada mahasiswa dari universitas muhammadiyah Purworejo. Mereka juga sering meluangkan waktu untuk berkumpul dan berbagi ilmu pada adik-adik yang ada si sekitar taman baca. Selain itu relawan atau tim pengajar hanya memiliki kompetensi dalam satu bidang saja. Oleh karena itu pelaksanaan penunjang pendidikan di Taman Bacaan Masyarakat berjalan kurang maksimal.

\subsection{Dampak Penerapan Program literasi melalui taman bacaan masyarakat di} Kelurahan Kedungsari Kabupaten Purworejo

Program kreatif sangatlah membantu memikat hati anak-anak untuk memulai belajar terutama dalam bidang membaca, anak yang sering bermain bisa diarahkan ke suatu kegiatan yang lebih bermanfaat dan lebih menambah ilmu pengetahuan serta wawasan mereka. Anak yg memiliki bakat bisa tersalurkan melalui kegiatan-kegiatan yang merangsang otak mereka untuk mengeluarkan bakat secara spontan, seperti kelas puisi yang telah diterapkan. Dengan adanya anak yang tampil membaca puisi di hadapan teman-temannya semua, maka teman-temannya yang lain akan ikut mau untuk tampil ke depan membaca puisi secara spontan, dengan ini secara tidak langsung anak-anak yang memiliki bakat untuk membaca puisi akan lebih terlihat.

Ketertarikan anak dengan media elektronik yang tidak terkontrol bisa membuat anak terpengaruh ke hal yang negatif contoh pengaruh media eloktronik smartphone yang mempunyai aplikasi game online yg membuat anak lupa akan kebersamaan dengan teman sebaya nya dan lupa dengan kewajiban mereka sebagai seorang pelajar. Dengan adanya program kreatif anak bisa diarahkan dan di bimbinng untuk menggunakan media elektronik secara lebih tepat dan mengarahkan mereka untuk menggunakan media elektronik di waktu-waktu tertentu saja, seperti hanya menggunakan smartphone mereka di sore hari saja dan mengembalikan pada orang tua sebelum jam 6 untuk disimpan.

Tidak hanya itu saja, setelah adanya program kreatif ini anak-anak sudah tidak asing lagi dengan buku bacaan, keberanian mereka berinteraksi dengan orang banyak sudah mulai meningkat atau dengan kata lain kepercayaan diri mereka berbicara di depan orang banyak sudah meningkat dibandingkan sebelumnya, mereka mendapatkan pengalaman-pengalaman baru karena dalam program kreatif ini mereka diperkenalkan dengan hal-hal yang baru bagi mereka, dan mereka sudah lebih bisa dalam berinteraksi sosial karena sebelumnya mereka cenderung dengan menyibukkan diri mereka masing-masing dibandingkan dengan lingkungan sosial mereka. 


\section{Kesimpulan}

Berdasarkan hasil kegiatan yang telah dilaksanakan dapat disimpulkan bahwa program literasi yang telah diterapkan di taman bacaan masyarakat Oemah Cendekia dapat berjalan dengan baik dan sukses. Kegiatan yang dilaksanakan meliputi: Serambi Baca Cendekia, Sinau Bareng Cendekia, dan Kreasi Cendekia. Meskipun demikian masih ditemui beberapa kendala seperti kurangnya koleksi buku dongeng yang bervariasi sangat, promosi baru dilaksankan pada ruang lingkup yang kecil; serta kurangnya relawan atau tim pengajar. Dampak penerapan program literasi di taman bacaan masyarakat Oemah Cendekia adalah (a) secara tidak langsung anak-anak secara spontan mengeluarkan bakat mereka yang tidak mereka sadari sebelumnya karena antusias mereka pada kegiatan ini; (b) meningkatkan kreatifitas, sensor motorik, afektif, kognitif dan psikomotor pada anak-anak karena kegiatan mereka sudah tidak selalu menggunakan gadget; (c) anak-anak sudah tidak asing dengan buku bacaan; dan (d) keberanian diri mereka berbicara di depan orang banyak semakin meningkat. Sebagai tindak lanjut, Oemah Cendekia dapat memperluas ruang lingkup dalam mempromosikan Taman Bacaan Masyarakat ini agar lebih dikenal oleh masyarakat luas.

\section{Acknowledgement}

Ucapan terima kasih ditujukan kepada Belmawa Ristekdikti melalui program PHP2D, Pemerintah desa beserta seluruh masyarakat Kedungsari yang menjadi mitra dalam kegiatan ini, serta seluruh pihak terkait yang telah mendukung dan mensukseskan pelaksanaan kegiatan ini.

\section{Daftar Pustaka}

Asyhari, A. (2015). Profil peningkatan kemampuan literasi sains siswa melalui pembelajaran saintifik. Jurnal Ilmiah Pendidikan Fisika Al-Biruni, 4(2), 179-191.

Ayuni, R. D., Siswati, S., \& Rusmawati, D. (2013). Pengaruh storytelling terhadap perilaku empati anak. Jurnal Psikologi, 12(2), 121-130.

Musfiroh, T., \& Listyorini, B. (2016). Konstruk kompetensi literasi untuk siswa sekolah dasar. Litera, 15(1).

Soleh, K., \& Nurhidayati, N. (2017). Gerakan Lierasi Sekolah Berbasis Kecerdasan Majemuk Berorientasi Pembelajar Sepanjang Hayat Bagi Guru Sd/Mi di Padureso Kebumen. Surya Abdimas, 1(1), 54-61. https://doi.org/10.37729/abdimas.v1i1.312

Suryaman, M. (2015). Analisis hasil belajar peserta didik dalam literasi membaca melalui studi internasional (PIRLS) 2011. Litera, 14(1).

Susanti, E., \& Syam, S. S. (2017). Peran Guru dalam Meningkatkan Kemampuan Literasi Matematika Siswa Indonesia. In Prosiding dipresentasikan dalam Seminar Matematika dan Pendidikan Matematika UNY.

Yuliati, Y. (2017). Literasi sains dalam pembelajaran IPA. Jurnal Cakrawala Pendas, 3(2). 